\title{
Bilateral Ureteral Stones Causing Anuria: A Case Report
}

\author{
Anüriye Neden Olan Bilateral Üreter Taşı: Olgu Sunumu
}

Ali Gür', Muhammet Gökhan Turtay', Şükrü Gürbüz1', Hakan Oğuztürk', M. Ediz Sarıhan', Fatih Oğuz², Serdar Derya'

'Department of Emergeny Medicine, Inönü University Faculty of Medicine, Malatya, Turkey

2Department of Urology, Inönü University Faculty of Medicine, Malatya, Turkey

\section{ABSTRACT}

Introduction: Bilateral ureteral stone is not known to frequently result in anuria during emergency.

Case Report: An 18-year-old male patient was admitted to an emergency department with the complaint of sudden inability to urinate. He did not mention any additional complaints. On conducting a physical examination, we could not detect any pathological findings. From the patient's blood tests, potassium and creatinine levels were found to be $6.4 \mathrm{mmol} / \mathrm{L}$ and $9.81 \mathrm{mg} /$ $\mathrm{dL}$, respectively. Subsequently, we found bilateral ureteral stones on ultrasonography and non-contrast spiral computed tomography. Urology consultation was requested. The patient undergoing emergency surgery had ureterorenoscopy, bilateral endoscopic retrograde basket, and DJ stents procedures done by urology. During the follow-up, the patient was able to urinate, and his creatinine and potassium levels decreased. The patient was discharged.

Conclusion: For patients admitted with complaint of anuria, we should keep in mind that the patient could have bilateral ureteral stones; therefore, he or she may have acute kidney failure and may subsequently require emergency surgery.

Keywords: Anuria, acute renal failure, bilateral ureteral stone Received: 13.02.2015 Accepted:01.07.2015

\section{ÖZET}

Giriş: Bilateral üreter taşı sonucu anüri acil serviste çok karşılaşılan bir durum değildir.

Olgu Sunumu: 18 yaşında erkek hasta ani idrar yapamama şikayeti ile acil servise başvurdu. Bu şikayeti dışında ek başka bir şikayeti olmadığını belirtti. Yapılan fizik muayenesinde herhangi bir patolojik bulgu saptanmadı. Yapılan kan tetkiklerinde hastanın potasyum değeri $6.4 \mathrm{mmol} / \mathrm{lt}$, kreatinin değeri ise 9.81 mg/dL'di. Daha sonrasında yapılan ultrasonografi ve kontrasız spiral tomografide bilateral üreter taşı tespit edildi. Üroloji konsültasyonu istendi. Üroloji tarafından acil cerrahiye alınan hastaya üreterorenoskopi ve DJ stent takılan hastanın böbrek fonksiyonlarının iyileşmesi ve idrar çıkışının olması ile hasta taburcu edildi.

Sonuç: Anüri şikayeti ile başvuran hastalarda, bilateral üreter taşı olabileceği ve buna bağlı olarak akut böbrek yetmezliği ve sonrasında acil cerrahi müdahale gerekebileceği akılda tutulmalıdır.

Anahtar Kelimeler: Anüri, akut böbrek yetmezliği, bilateral üreter taşı

Geliş Tarihi: 13.02.2015 Kabul Tarihi: 01.07.2015

\section{Introduction}

Anuria is urinary output of less than $50 \mathrm{~mL}$ per day or no urinary output. The causes of anuria are total urinary tract obstruction, total renal artery or vein occlusion, and shock (1). The other causes of anuria are bilateral cortical necrosis, acute tubular necrosis, and rapidly progressive glomerulonephritis (1). As classical signs and symptoms of ureteral stones may be flank pain and hematuria in the initial stages, these patients may also be admitted with atypical complaints as inability to urinate (2). Ureteral stones of $0.72 \%$ have led to acute renal failure (3). In this case, we aimed to present a case of an 18-year-old male patient admitted to our emergency department with the complaints of anuria; he also had acute renal failure and bilateral ureteral stones.

\section{Case Report}

An 18-year-old male patient was admitted to the emergency department with the complaint of a sudden inability to urinate. He noted that there were no additional complaints. He had no clinical features according to his medical history. The patient's vital signs were stable. On conducting a physical examination, we detected no costovertebral angle tenderness and pathological 


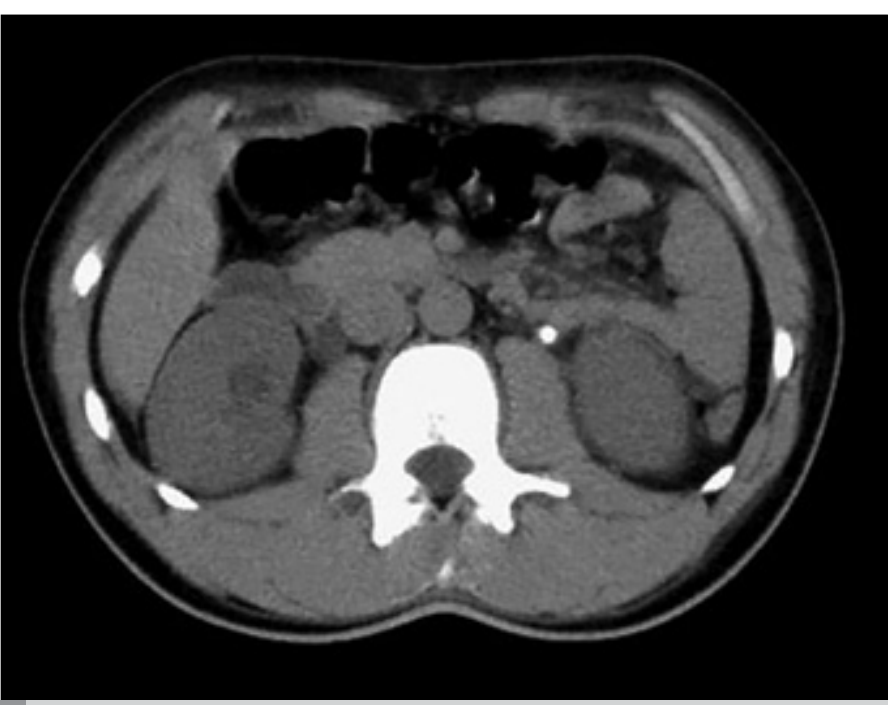

Figure 1. It appears in the left ureteral stone in computed tomography.

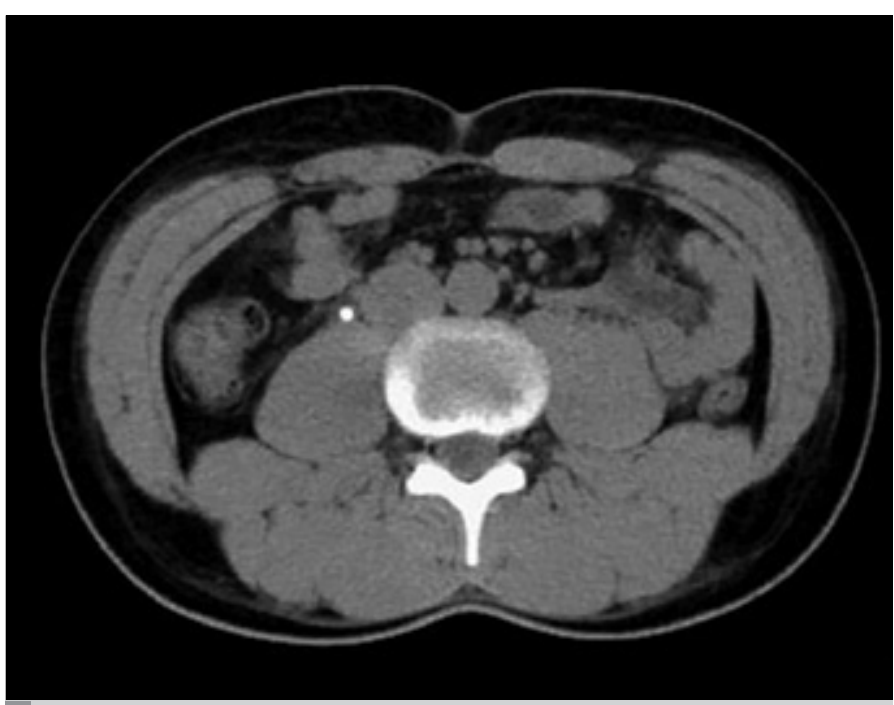

Figure 2. It appears in the right ureteral stone in computed tomography.

findings. We inserted a Foley catheter, but the patient did not have urinary output. An electrocardiogram (ECG) was obtained. T-wave acicularity was significant on ECG. From the patient's blood tests, we found that white blood cell value was $14300 / \mathrm{mL}$, urea level was 46 $\mathrm{mg} / \mathrm{dL}$, potassium level was $6.4 \mathrm{mmol} / \mathrm{L}$, and creatinine level was $9.81 \mathrm{mg} / \mathrm{dL}$. Subsequently, we performed ultrasonography (USG) and non-contrast spiral computed tomography; bilateral ureteral stones were found. USG showed that renal parenchymal echo increased to grade $\mathrm{I}$, and the right renal ureter was $1.2 \mathrm{~cm}$ in diameter and the left renal ureter was $7 \mathrm{~mm}$ in diameter in both of which several pieces of stones were observed. Right and left renal pelvis and both of the proximal ureter segments were dilated. Computed tomography findings seemed to support those of USG (Figure 1 and 2). The patient's medical treatment was immediately started, and urology consultation was requested. The patient undergoing emergency surgery had ureterorenoscopy, bilateral endoscopic retrograde basket, and DJ stents done by urology. During the follow-up, the patient's urinary output started, and his creatinine and potassium levels decreased $(1.3 \mathrm{mg} / \mathrm{dL}$ and $4.9 \mathrm{mmol} / \mathrm{L}$, respectively). The patient was discharged.

\section{Discussion}

The most frequent causes of anuria are total urinary tract obstruction, total renal artery or vein occlusion, and shock (1). Fifty-four percent of uric acid stones that form anuria are bilaterally located (4). The other causes of anuria are bilateral cortical necrosis, acute tubular necrosis, and rapidly progressive glomerulonephritis (1). Obstructing ureterolitihs rarely lead to acute kidney failure without some underlying renal diseases or anatomic abnormalities such as a solitary kidney or horseshoe kidney (5). Acute kidney failure has been defined in multiple studies with varying changes in serum creatinine, urinary output, need for renal replacement therapy, and estimated glomerular filtration rate (6). Acute reversible kidney failure secondary to bilateral ureteral obstruction is a common urological problem (6). In our case, anuria was induced by bilateral ureteral stones, resulting in the development of acute renal failure. Nevertheless, to our knowledge, there is currently no published study regarding the incidence and clinical features of acute kidney failure secondary to ureteral calculi (3). We have not encountered bilateral ureteral stones causing anuria in any of the studies in the Turkish literature. The signs and symptoms of acute renal failure because of bilateral ureteral stones may be asymptomatic (2). However, in these patients, blood test levels, such as potassium levels, are very important and should be noted. In our case, we examined a patient having anuria and high potassium level in acute renal failure but not having any pain and hematuria. Most of the acute renal failures with bilateral ureteral stones are seen in the pediatric age group (7). As our case is about an 18-yearold adult patient, it is different from most pediatric cases in the literature. The treatment of acute renal failure caused by bilateral ureteral stones is by ureteroscopy and percutaneous nephrostomy (3). Therefore, in our case, after bilateral ureterorenoscopy and DJ stent administration, the patient was discharged.

\section{Conclusion}

For adults patients admitted with a complaint of anuria, it should be noted that bilateral ureter stone may be a cause of anuria, and the patient may have acute kidney failure; in this condition, emergency medical treatments should be started immediately prior to emergency surgery.

Informed Consent: Written informed consent was obtained from patient who participated in this case.

Peer-review: Externally peer-reviewed.

Author Contributions: Concept - M.G.T.; Design - S..G.; Supervision H.O.; Materials - M.E.S.; Data Collection and/or Processing - F.O.; Analysis and/or Interpretation - S.D.; Literature Review - Ş.G.; Writer - A.G.; Critical Review - M.G.T.

Conflict of Interest: The authors declared no conflict of interest

Financial Disclosure: The authors declared that this study has received no financial support. 
Hasta Onamı: Yazılı hasta onamı bu olguya katılan hastadan alınmıştır.

Hakem değerlendirmesi: Dış bağımsız.

Yazar Katkıları: Fikir - M.G.T.; Tasarım - Ş.G.; Denetleme - H.O.; Malzemeler - M.E.S.; Veri toplanması ve/veya işlemesi - F.O.; Analiz ve/ veya yorum - S.D.; Literatür taraması - Ş.G.; Yazıyı yazan - A.G.; Eleştirel Inceleme - M.G.T.

Çıkar Çatışması: Yazarlar çıkar çatışması bildirmemişlerdir.

Finansal Destek: Yazarlar bu çalışma için finansal destek almadıklarını beyan etmişlerdir.

\section{References}

1. Altıparmak MR. Anürik hastaya yaklaşım. I.Ü. Cerrahpaşa Tıp Fakültesi Sempozyum Dizisi 2002; 29: 237-45.
2. Cara Fuentes GM, Espinosa Roman L, Melgosa Hijosa M, Navarro Torres $M$. Acute renal failure due to bilateral pieloureteral stone impaction in a 10-month-old boy. Clin Exp Nephrol 2010; 14: 401-3. [CrossRef]

3. Wang SJ, Mu XN, Zhang LY, Liu QY, Jin XB. The incidence and clinical features of acute kidney injury secondary to ureteral calculi. Urol Res 2012; 40: 345-8. [CrossRef]

4. Joual A, Dakir M, el Mrini M, Benjelloun S. Calculus-induced anuria. Apropos of 25 cases. Ann Urol (Paris) 1997; 31: 191-4.

5. Jason R. Stone, Tristan L. Knutson Christopher KangBilateral obstructing renal stones: an uncommon cause of acute renal failure. Am J Emerg Med 2010; 28: 390.e5-6.

6. Savić S, Vukotić V, Lazić M, Savić N. Management of Calculus Anuria Using Ureteroscopic Lithotripsy as a First Line Treatment: Its Efficacy and Safety. Urol J 2014; 11: 1392-9.

7. Sinha R, Agarwal I. Anuria in an infant secondary to bilateral ureteric stones. Clin Exp Nephrol 2010; 14: 520-1.[CrossRef] 